\title{
Moisture stress induced changes in metabolites and cellular functions in chickpea (Cicer arietinum $\mathbf{L}$.) genotypes
}

\author{
Navkiran Randhawa ${ }^{1 *}$, Jagmeet Kaur ${ }^{1}$, Satvir Kaur ${ }^{2}$ and Sarvjeet Singh ${ }^{1}$ \\ ${ }^{1}$ Department of Plant Breeding and Genetics, Punjab Agricultural University, Ludhiana- 141004 (Punjab), INDIA \\ ${ }^{2}$ Department of Biochemistry, Punjab Agricultural University, Ludhiana- 141004 (Punjab), INDIA \\ *Correrspnding author. E mailnavkiran.randhawa85@gmail.com \\ Received: June 20, 2015; Revised received: October 10, 2015; Accepted: February 17, 2016
}

\begin{abstract}
The present investigation was aimed to study influence of moisture stress in in vitro identified tolerant (GL28151, RSG963, PDG3) and sensitive (GL22044, GNG1861, PBG1) chickpea genotypes under field conditions. Moisture stress treatments included crop sown with one pre-sowing irrigation (WS $S_{\mathrm{VF}}$ ), irrigation withheld at flower initiation stage $\left(\mathrm{WS}_{\mathrm{F}}\right)$, irrigation withheld at pod initiation stage $\left(\mathrm{WS}_{\mathrm{P}}\right)$ and control (irrigated as and when required). Osmolytes (in seeds) viz. total soluble sugars, starch, proline, cellular functions; relative water content, membrane permeability index and lipid peroxidation (in leaves), antioxidant enzymes (at pod filling stage) viz. peroxidase, catalase, superoxide dismutase, glutathione reductase were estimated in chickpea seeds under control and stressed conditions. WS $S_{V F}$ was most severely affected by moisture stress followed by WS $\mathrm{S}_{\mathrm{P}}$ and $\mathrm{WS}_{\mathrm{F}}$ and emphasized on pod intuition stage as critical stage attributable to hindered transport of assimilates towards formation of pods and development of seeds under stress imposed by lack of sufficient moisture. Highest accumulation of total soluble sugars (73.33), starch (73.12), proline (2.04) in $\mathrm{mg} / \mathrm{g}$ fresh weight, least percentage reduction over control in relative water content (20.3), membrane permeability index (18.8) and minimal lipid peroxidation (31.3) accompanied by significantly enhanced activities of antioxidant enzymes under WS VFP rendered moisture stress tolerance in RSG963. The pronounced cellular damage, lesser alleviation in the content of osmolytes, antioxidant enzymes activity was observed in sensitive genotype GL22044 under stress treatments. High molecular weight protein bands were found either absent or of low intensity in sensitive genotypes (GL22044, GNG1861 and PBG1) under severe stress treatment (WS $\mathrm{VFP}$ ).
\end{abstract}

Key words: Biochemicals, Cellular Chickpea, Cicer arietinum, Moisture stress

\section{INTRODUCTION}

Lack of moisture in the soil imposes deleterious influence on the morphology, physiology, biochemistry of plant, causing altered metabolic processes and reduction in economic yield. Chickpea (Cicer arietinum L.) is the third most important food legume which had a total global production of $13.1 \mathrm{M}$ tons from $13.5 \mathrm{M}$ ha in 2013 (FAOSTAT 2014). High protein content, wide climatic adaptations, nitrogen fixation ability, low production cost favours wide cultivations of chickpea, as a cool season legume crop. Crop often suffers from drought at the end of the cropping season, due to untimely and insufficient rainfall. Although, general effects of drought on plant growth are fairly well known, the primary effects of water deficit at the biochemical and molecular levels are not well understood (Bhatnagar-Mathur et al 2009).

A wide range of physiological and biochemical adaptations allow the survival of crop when faced with drought stress. These strategies involve maintenance of optimum water potential by accumulation of compatible solutes such as soluble carbohydrates and proline in cytoplasm and active antioxidant defense mechanism which protect cell structure against damage induced by dehydration and oxidation. Soluble sugars are basic constituents of metabolic pool in plants, utilized as precursors for numerous biosynthetic pathways and play role in signaling during abiotic stress (Sunkar 2010). Accumulation of proline, influences protein salvation, preserves quaternary structure of complex proteins, reduces oxidation of lipid membranes and play important role in scavenging free radicals under moisture stress conditions (Raheleh et al 2012). Relative water content is an important physiological trait related with osmoregulation and serves as a quick method for screening drought tolerant varieties.

Another common consequence of drought stress is an increased production of toxic reactive oxygen species such a superoxide dismutase $\left(\mathrm{O}_{2}{ }^{-}\right)$, hydrogen peroxide $\left(\mathrm{H}_{2} \mathrm{O}_{2}\right)$ and hydroxyl radical $(\mathrm{OH})$ (Masoumi et al 2011). Lipid Peroxidation and damaged membrane integrity are key indicators of oxidative stress and are negatively correlated with the growth of crop. Plants have developed a dynamic defense mechanism comprising of various antioxidant enzymes, such as super- 
oxide dismutase (SOD), peroxidase (POD) and catalase (CAT), glutathione reductase (GR) and non enzymatic antioxidants, such as ascorbic acid and reduced glutathione $(\mathrm{GSH})$ to cope with moisture stress. Water stress cause both reductions in the rate of protein synthesis as well as the changes in the type of proteins produced, these stress induced proteins allow plants to make biochemical and structural adjustments that enable plants to cope with the stress (Pratap and Sharma 2010).

Keeping the above in view, the present investigation was carried out with an objective to understand biochemical mechanism of drought tolerance by measuring relative content of total soluble sugars, starch, proline, water content, membrane permeability, lipid peroxidation, activity of antioxidant enzymes viz. peroxidase, catalase, superoxide dismutase in chickpea, profiling of induced proteins.

\section{MATERIALS AND METHODS}

The seeds of chickpea (Cicer arietnum L.) tolerant (GL28151, RSG963, PDG3) and sensitive (GL22044, GNG1861, PBG1) genotypes selected on the basis of in vitro studies conducted under various osmotic concentration levels, were procured from Department of Plant breeding and Genetics, Punjab Agricultural University, India, and grown in experimental field area under varied water stress treatments. Each genotype was grouped in four sets viz., irrigated as and when required (C), sown with one pre-sowing irrigation $\left(\mathrm{WS}_{\mathrm{VFP}}\right)$, stressed at flower initiation $\left(\mathrm{WS}_{\mathrm{F}}\right)$ and stressed at pod initiation $\left(\mathrm{WS}_{\mathrm{P}}\right)$. The experiment was laid out in a split plot design with three replications.

At harvest, mature seeds were taken to analyze biochemical changes in the osmolytes and for protein profiling. Leaves at 120 DAS were collected to study membrane permeability index, relative leaf water content and lipid peroxidation. Fresh chickpea seeds, at 120 DAS stressed at varied growth stages were used to determine activity of antioxidant enzymes.

Extraction and assay of biochemicals: Mature seed samples of known weights were collected and homogenized in $80 \%$ ethanol and centrifuged. The residue was re-extracted to ensure complete extraction; supernatants were pooled and used for estimation of total soluble sugars. Residue left after ethanol extraction was kept for analyzing starch content. Sugars and starch was estimated by method given by Dubois et al (1956). Proline content was measured by method given by Bates et al (1973). Sugars, starch and proline content was expressed as $\mathrm{mg} \mathrm{g}^{-1}$ dry weight.

Membrane permeability index and Relative water content (RWC): The percent leakiness of seedling was determined following the method of Fletcher and Drexlure (1980).

Relative water content was recorded from the leaves of control and stressed plants by following method given by Weatherly (1950).
RWC $=\underline{\text { Fresh weight- Dry weight }} \times 100$ Saturated weight - Dry weight

Lipid peroxidation: Lipid peroxidase formation was studied by Thiobarbituric acid (TBA) color reaction in leaf sample by following method of Bernheim et al (1948). Malondialdehyde (MDA) content formed was expressed as $\mu$ moles $\mathrm{g}^{-1}$ dry weight.

Extraction and assay of antioxidant enzymes: Developing seeds at podding stage were taken from various stress treatments and control for studying antioxidant enzyme activity. All the enzymes were extracted at $4^{\mathrm{O}} \mathrm{C}$ to minimize denaturation and assayed at $30^{\circ} \mathrm{C}$.

Extraction of assay of peroxidase: The enzyme was extracted from the fresh seed samples with $0.1 \mathrm{M}$ potassium phosphate buffer ( $\mathrm{pH} 7.5$ ) containing 1\% PVP, $1 \mathrm{mM}$ EDTA and $10 \mathrm{mM} \beta$ - mercaptoethanol by standard methods of Kar and Mishra 1976. The extracts were centrifuged at $10,000 \mathrm{~g}$ for 10 minutes. The reaction mixture contained $3 \mathrm{ml}$ of $0.05 \mathrm{M}$ guaiacol prepared in $0.1 \mathrm{M}$ potassium phosphate buffer $(\mathrm{pH} 6.5)$, $0.1 \mathrm{ml}$ of enzyme extract and $0.1 \mathrm{ml}$ of $0.8 \mathrm{M} \mathrm{H}_{2} \mathrm{O}_{2}$. The reaction mixture without $\mathrm{H}_{2} \mathrm{O}_{2}$ was measured as a blank. The reaction was initiated by adding $\mathrm{H}_{2} \mathrm{O}_{2}$ and rate of change in absorbance was recorded at $470 \mathrm{~nm}$ for 3 minutes at an interval of 30 seconds. Peroxidase activity has been defined as change in absorbance min $^{-}$ ${ }^{1} \mathrm{~g}^{-1}$ fresh weight.

Extraction and assay of superoxide dismutase: Enzyme extract was obtained by same procedure given for peroxidase (Kar and Mishra 1976). In a cuvette, $1.5 \mathrm{ml}$ of $0.1 \mathrm{M}$ Tris-HCL buffer ( $\mathrm{pH} \mathrm{8.2),} 0.5 \mathrm{ml}$ of 6 $\mathrm{mM}$ EDTA, $1 \mathrm{ml}$ of $6 \mathrm{mM}$ pyrogallol solution and 0.1 $\mathrm{ml}$ of enzyme extract was added. Absorbance was recorded at $420 \mathrm{~nm}$ after an interval of 30 seconds upto 3 minutes. A unit of enzyme activity has been defined as the amount of enzyme causing $50 \%$ inhibition of autooxidation of pyrogallol observed in blank. Superoxide dismutase was expressed as unit enzyme $\mathrm{g}^{-1}$ fresh weight (Nishikami et al 1972).

Extraction and assay of catalase: The enzyme was extracted with $50 \mathrm{mM}$ sodium phosphate buffer $(\mathrm{pH}$ 7.5) containing $1 \%$ polyvinyl pyrrolidine. In spectrophotometric cuvette, $1.8 \mathrm{ml}$ of $50 \mathrm{mM}$ sodium phosphate buffer $(\mathrm{pH} \mathrm{7.5)}$ and $0.2 \mathrm{ml}$ of enzyme extract was added as per the standard methods of Kar and Mishra 1976. The reaction was initiated by adding $\mathrm{H}_{2} \mathrm{O}_{2}$ and utilization of $\mathrm{H}_{2} \mathrm{O}_{2}$ was recorded at intervals of 30 seconds for 3 minutes by measuring the decrease in absorbance at $240 \mathrm{~nm}$. Catalase activity was expressed as $\mu$ moles of $\mathrm{H}_{2} \mathrm{O}_{2}$ decomposed $\min ^{-1} \mathrm{~g}^{-1}$ fresh weight.

Extraction and assay of glutathione reductase: The tissue $(100 \mathrm{mg}$ ) was extracted with $2 \mathrm{ml}$ of ice cold 0.1 $\mathrm{M}$ Tris HCL buffer ( $\mathrm{pH} 7.5)$ containing 1mM EDTA, $1 \%$ PVP, $10 \mathrm{mM} \beta$-mercaptoethanol, using pestle and mortar. Homogenate was centrifuged at $10000 \mathrm{~g}$ at $4^{\circ} \mathrm{C}$ for 20 minutes and clear supernatant was used for enzyme assay as per the standard methods of Esterbauer 
Navkiran Randhawa et al. / J. Appl. \& Nat. Sci. 8 (1) : 225- 231 (2016)
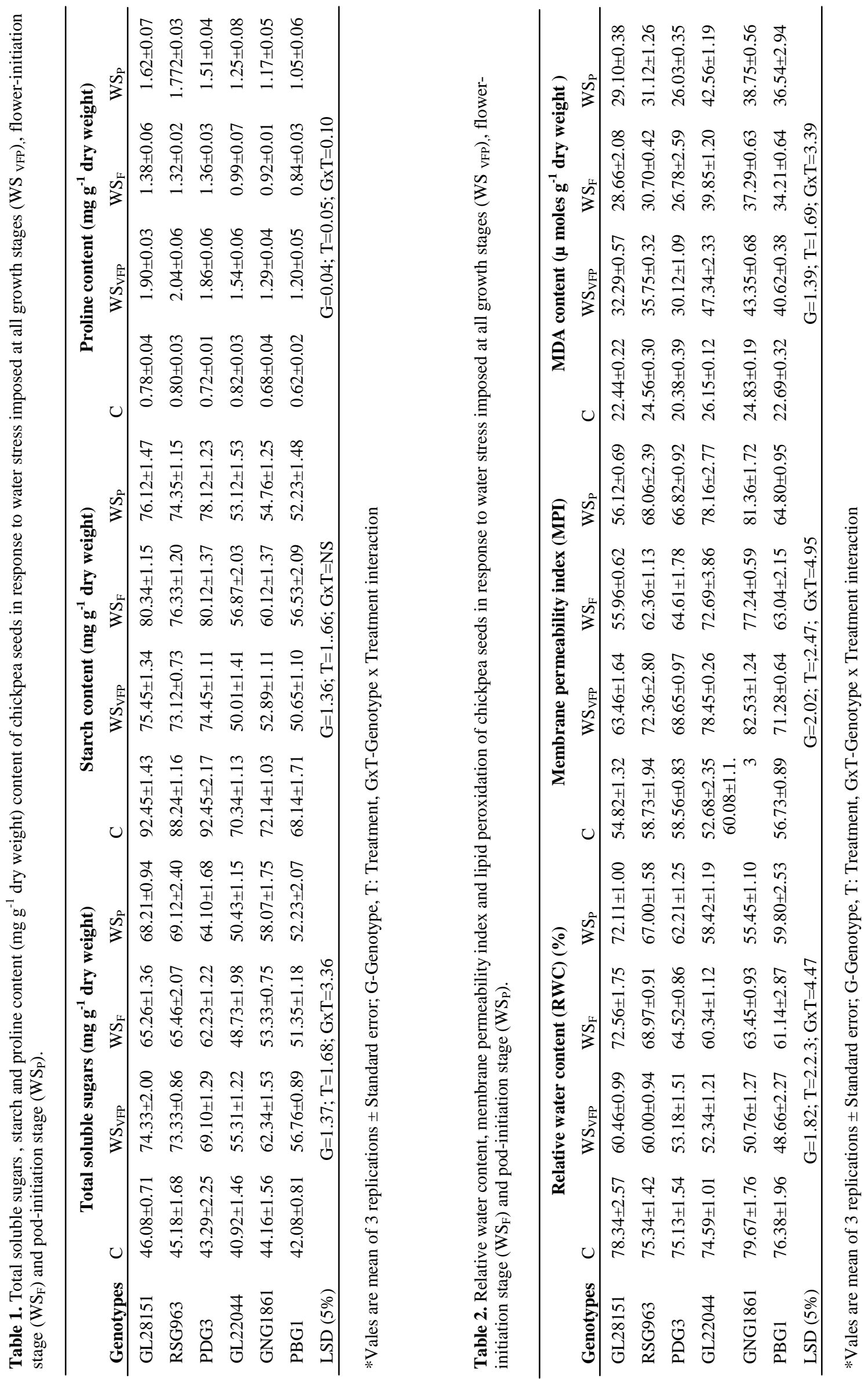


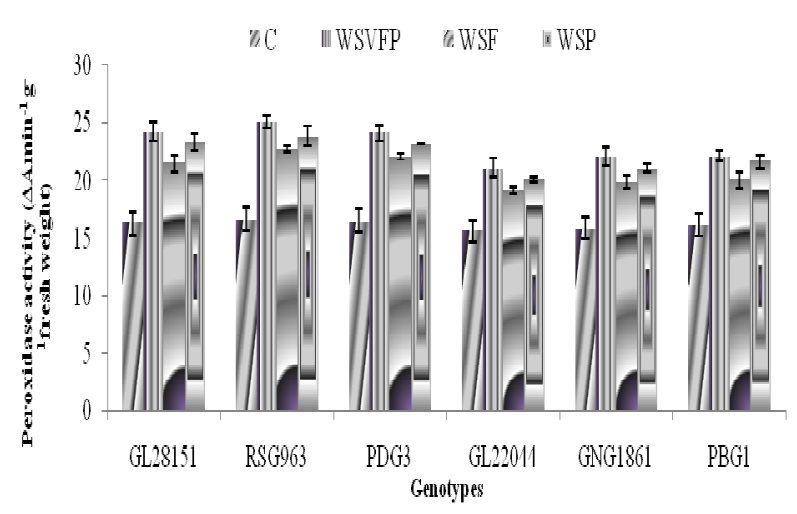

Fig. 1. Peroxidase activity $\left(\triangle A \mathrm{~min}^{-1} \mathrm{~g}^{-1}\right.$ fresh weight) of various chickpea in response to water stress imposed at all growth stages $\left(W S_{V F P}\right)$, flower-initiation stage $\left(W S_{F}\right)$ and pod-initiation stage $\left(W S_{P}\right)$.

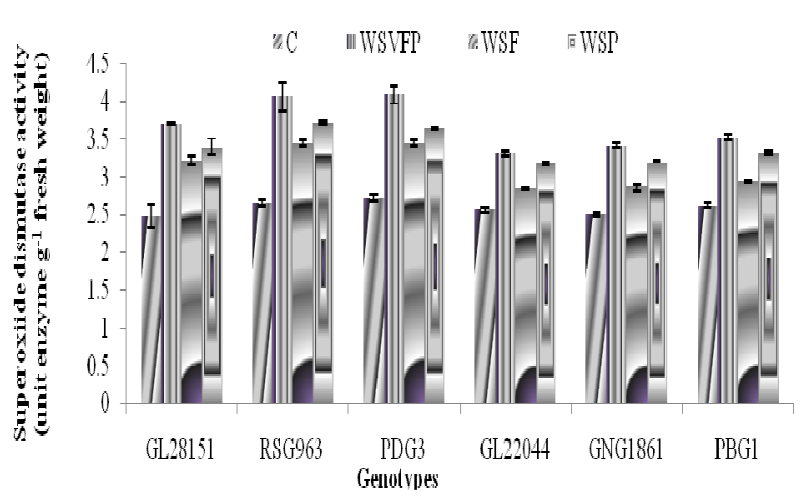

Fig. 2. Superoxide dismutase (unit enzyme $g^{-1}$ fresh weight) of various chickpea genotypes in response to water stress imposed at all growth stages (WS VFP), flower-initiation stage $\left(W S_{F}\right)$ and pod-initiation stage $\left(W S_{P}\right)$.

and Grill 1978. To the spectrophotometric cuvette, 0.2 $\mathrm{ml}$ of $0.1 \mathrm{M}$ Tris $\mathrm{HCl}$ buffer $(\mathrm{pH} 7.5), 0.1 \mathrm{ml}$ of 1.5 $\mathrm{mM} \mathrm{MgCl} 2,0.1 \mathrm{ml}$ EDTA $(0.2 \mathrm{mM}), 0.2 \mathrm{ml}$ of 0.5 $\mathrm{mM}$ NADPH and $0.2 \mathrm{ml}$ of enzyme extract and then $0.2 \mathrm{ml}$ of $2 \mathrm{mM}$ oxidized glutathione was added. The enzyme activity was estimated as the decrease of absorbance at $340 \mathrm{~nm}$ after an interval of 30 seconds upto 3 minutes. The molar extinction coefficient for NADPH is $6.22 \mathrm{mM}^{-1} \mathrm{~cm}^{-1}$. Glutathione reductase activity was expressed as $\mu$ moles of NADP formed min ${ }^{1} \mathrm{~g}^{-1}$ fresh weight of leaf tissue

Statistical analysis: The data on various parameters were subjected to statistical analysis. Critical difference values were calculated by analysis of variance (ANOVA).

Protein profiling: Protein content of control and treatment $\left(\mathrm{WS}_{\mathrm{VFP}}\right)$, sown with one presowing irrigation was analyzed using SDS PAGE was by Laemmli (1970).

\section{RESULTS AND DISCUSSION}

Total soluble sugars, proline and starch content: Total soluble sugars and proline content was found low in seeds under control conditions, while it enhanced

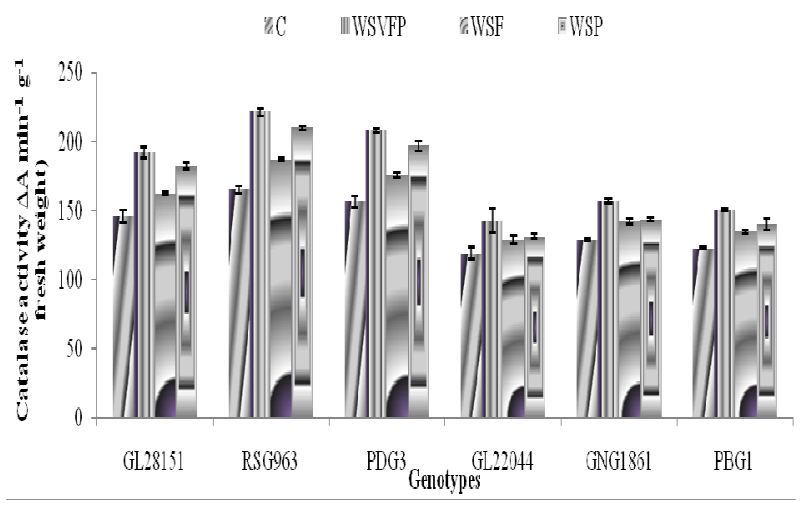

Fig. 3. Catalase ( $\triangle A \mathrm{~min}^{-1} \mathrm{~g}^{-1}$ fresh weight) of various chickpea genotypes in response to water stress imposed at all growth stages (WS $\left.{ }_{V F P}\right)$, flower-initiation stage $\left(W S_{F}\right)$ and pod-initiation stage $\left(W S_{P}\right)$.

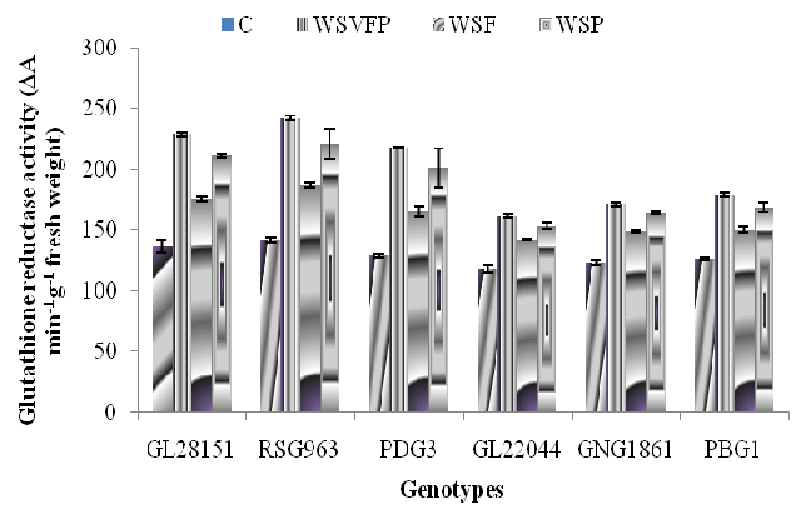

Fig. 4. Glutathione reductase activity $\left(\triangle A \mathrm{~min}^{-1} \mathrm{~g}^{-1}\right.$ fresh weight) of various chickpea genotypes in response to water stress imposed at all growth stages (WS VFP), flowerinitiation stage $\left(W S_{F}\right)$ and pod-initiation stage $\left(W S_{P}\right)$.

noticeably under various water stress treatments (Table 1). Sharp increase was noticed under $\mathrm{WS}_{\mathrm{VFP}}$, followed by $\mathrm{WS}_{\mathrm{P}}$ and $\mathrm{WS}_{\mathrm{F}}$ stress treatments. Under $\mathrm{WS}_{\mathrm{VFP}}$, percent increase was highest in GL28151 (38.4), while least increase was noticed in PBG1 (25.9). The percent increase in total soluble sugars at pod-initiation stage among tolerant genotypes was recorded maximum in RSG963 under $\mathrm{WS}_{\mathrm{F}}(3.10)$ and $\mathrm{WS}_{\mathrm{P}}(34.6)$ stress treatments. Among sensitive genotypes, minimal percent increment was observed in GL22044 under $\mathrm{WS}_{\mathrm{F}}$ (16.0) and $\mathrm{WS}_{\mathrm{P}}(18.9)$ stress treatments. The variations in proline content estimated in dry chickpea seeds is shown in Table 1. Percent increase was highest in PDG3 under $\mathrm{WS}_{\mathrm{VFP}}$ (61.3) and $\mathrm{WS}_{\mathrm{F}}$ (47.1) stress treatments. However, RSG963 showed higher increase in percentage under stress treatment $\mathrm{WS}_{\mathrm{P}}$ (53.5). Comparatively lesser increase was shown by sensitive genotypes, among them, GL22044 showed least increase in percentage under $\mathrm{WS}_{\mathrm{VFP}}(46.8), \mathrm{WS}_{\mathrm{F}}(17.2)$ and $\mathrm{WS}_{\mathrm{P}}(34.4)$ respectively.

Starch content was greater in seeds grown under control conditions, and showed progressive decrease under water stress treatments (Table 1). Under stress treat- 
Plate 1. SDS PAGE Electrophoresis of of various chickpea genotypes under control (C) and stress treatment sown with one pre-sowing irrigation ( $\mathrm{WS}_{\mathrm{VFP}}$ ).

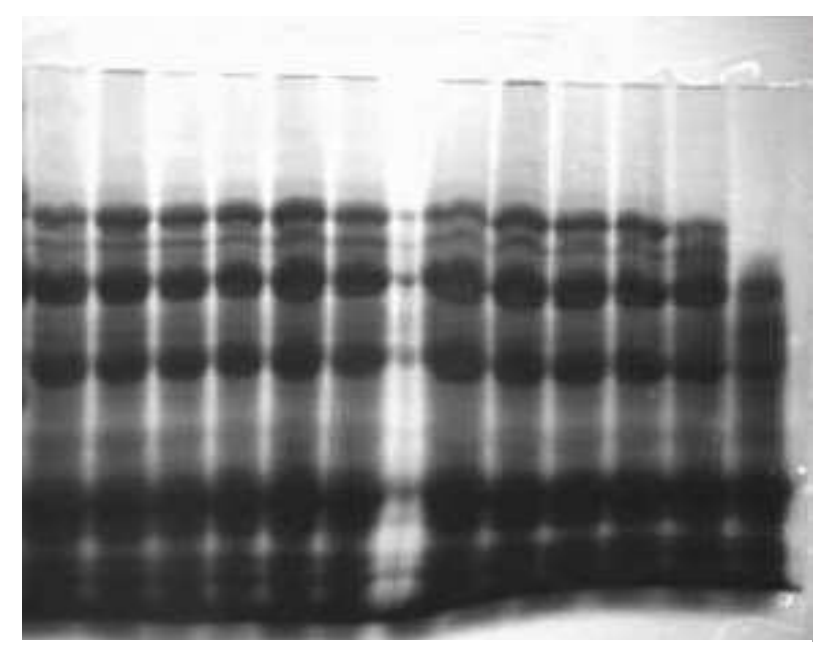

1-GL28151, 2-RSG963, 3-PDG3, 4-GL22044, 5-GNG1861, 6-PBG1 under control conditions

1'-GL28151， 2'-RSG963， 3'-PDG3， 4'-GL22044， 5'GNG1861, 6'-PBG1 under $\mathrm{WS}_{\mathrm{VFP}}$ Treatment

ments, percent decrease over control was highest in sensitive genotype GL22044 under treatments $\mathrm{WS}_{\mathrm{VFP}}$ (28.9), $\mathrm{WS}_{\mathrm{F}}$ (19.1) and $\mathrm{WS}_{\mathrm{P}}$ (24.5). Percentage decline was minimum in tolerant genotype RSG963 under $\mathrm{WS}_{\mathrm{VFP}}$ (17.1), however GL28151 and PDG3 showed least percentage reduction under water stress treatment $\mathrm{WS}_{\mathrm{F}}$ (13.1) and $\mathrm{WS}_{\mathrm{P}}$ (15.5) respectively.

Maintenance of plant water status is a fundamental phenomenon for the maintenance of normal growth of plants under stressful environment (Ali and Ashraf 2011). Osmotic adjustment ranges between 0 to 1.3 MPa (Moinuddin and Khanna Chopra 2004) in chickpea, and plays pivotal role in adaptation of crop to water deficit conditions. Present study suggests alleviation in soluble sugars and proline, while storage compound starch declined as the stress increased. Changes in quantity of soluble sugars in association with water stress may be due to increased sugar biosynthesis, conversion of storage forms of carbohydrates to soluble sugars, breakdown of cell wall polysaccharides and changes in rate of sugar transport (Sunkar 2010). Under water stress conditions, lowered water potential is accompanied by breakdown of starch by hydrolytic enzymes amylases, into glucose and maltose, which increases the osmotic concentration of cell. As a result, cellular turgor, expansion growth, uptake of water and minerals through root is maintained. Proline is a protective osmolyte that accumulates faster than other amino acids, shows multifarious role in drought tolerance reactive oxygen species scavenger, and protection from oxidative damage and stabilizing enzymatic proteins against desiccation. Enzymes involved in proline biosynthesis elevates under drought stress, whereas those of degradation are inhibited (Sumithra and Reddy 2004). Tolerant genotypes accumulated greater contents of sugars and proline in comparison to sensitive ones enabling organelles and cytoplasmic activities to take place at normal pace, regulating optimum growth, photosynthesis and helping optimum translocation of photo-assimilates towards grain filling under water deficit conditions. Similar results were reported by Basu et al (2007) in chickpea.

Relative leaf water, membrane permeability index and lipid peroxidation: Decline in relative leaf water content and increase in membrane leakage was observed under all stress treatments. Maximum influence was noticed under treatment $\mathrm{WS}_{\mathrm{VFP}}$ followed by $\mathrm{WS}_{\mathrm{P}}$ and $\mathrm{WS}_{\mathrm{F}}$. Least reduction was noticed in RWC of RSG963 (20.36\%) under treatment $\mathrm{WS}_{\mathrm{VFP}}$ while GL28151 showed minimum reductions of $7.38 \%$ and $7.95 \%$ under treatment $\mathrm{WS}_{\mathrm{P}}$ and $\mathrm{WS}_{\mathrm{F}}$ respectively (Table 2). Whereas, sensitive genotypes showed sharp reduction in their relative water content under stress, however difference within the genotypes followed no specific pattern under variable stress treatments. Membrane permeability index showed significant increase under stress treatments over control (Table 2). Least alterations were recorded in tolerant genotypes, RSG963 under treatments $\mathrm{WS}_{\mathrm{VFP}}(18.84 \%), \mathrm{WS}_{\mathrm{F}}$ $(5.83 \%)$ while in PDG3 $(13.72 \%)$ under treatment $\mathrm{WS}_{\mathrm{P}}$. However, pronounced alterations were observed in GL22044 (27.65\%) under treatment $\mathrm{WS}_{\mathrm{VFP}}$, while in GNG1861 showing increase of $22.22 \%$ and $26.16 \%$ under $\mathrm{WS}_{\mathrm{F}}$ and $\mathrm{WS}_{\mathrm{P}}$ respectively.

Extent of lipid peroxidation incremented as the magnitude of stress imposed increased, following similar trend where $\mathrm{WS}_{\mathrm{VFP}}$ was affected most, followed by $\mathrm{WS}_{\mathrm{P}}$ and $\mathrm{WS}_{\mathrm{F}}$. Increase in percentage was minimal in GL28151 under $\mathrm{WS}_{\mathrm{VFP}}(30.5), \mathrm{WS}_{\mathrm{P}}$ (22.9) stress treatments, while under $\mathrm{WS}_{\mathrm{F}}$, RSG963 showed minimum increase of $20.0 \%$ (Table 2). Highest increase of 44.8 , 34.4 and 38.5 percent was noticed in GL22044 under $\mathrm{WS}_{\mathrm{VFP}}, \mathrm{WS}_{\mathrm{F}}$ and $\mathrm{WS}_{\mathrm{P}}$ stress treatments respectively.

Optimum relative water content is crucial for efficient physiological functioning and growth processes of crop and has been identified as potential physiological marker in many crops. Relative water content declined in present study under moisture stress conditions. It may be attributed to water loss through stomatal mechanism during photosynthesis and inefficient water assimilation under drought stress (Lobato et al 2008). Unchanged RWC in tolerant genotypes in comparison to sensitive ones showed that they have mechanisms to control degree of cell and tissue hydration under water stress by regulating stomatal opening. Results are in accordance to that observed by Sepanto et al (2014) in soybean. Reactive oxygen species are formed as byproduct in electron transport chains of chloroplasts, mitochondria and plasma membrane and initiate lipid peroxidation and degrade proteins, lipids and nucleic acids (Hendry 2005), leading to enhanced membrane leakage. Lipid Peroxidation measured as the amount of 
malondialdehyde formed which is most abundant aldehydic lipid breakdown product. Electrolyte leakage is mainly related to $\mathrm{K}^{ \pm}$efflux from plant cells, which is mediated by plasma membrane $\mathrm{K}^{ \pm}$permeable channels (Demidchik et al 2014). This study indicates pronounced enhancement in lipid peroxidation and membrane leakage as the magnitude of stress enhanced. Similar results were observed by Patel et al (2011) in chickpea.

Antioxidant Enzymes: Antioxidant activity was found to show tremendous increase in seeds under $\mathrm{WS}_{\mathrm{VFP}}$, followed by $\mathrm{WS}_{\mathrm{P}}$ and $\mathrm{WS}_{\mathrm{F}}$ stress treatments. Higher increase was observed in tolerant than sensitive genotypes. Percent increase in peroxidase activity was highest in RSG963 under stress treatments $\mathrm{WS}_{\mathrm{VFP}}$ (33.7) and $\mathrm{WS}_{\mathrm{F}}(26.8)$, while under $\mathrm{WS}_{\mathrm{P}}$, greater percent increase of 30.3 closely followed by 30.2 was found in GL28151 and RSG963 respectively (Fig. 1). Increase in percentage was found least in GL22044 under $\mathrm{WS}_{\mathrm{VFP}}$ (25.9), $\mathrm{WS}_{\mathrm{F}}$ (18.3) and $\mathrm{WS}_{\mathrm{P}}(22.2)$ water stress treatments. Variation in superoxide dismutase activity is shown in Fig. 2. Highest percentage increase was recorded in RSG963 under stress treatments $\mathrm{WS}_{\mathrm{VFP}}(34.7), \mathrm{WS}_{\mathrm{F}}$ (23.2) and $\mathrm{WS}_{\mathrm{P}}$ (28.8) among tolerant genotypes, while least increment in percentage within sensitive genotypes was observed in GL22044 under stress treatments $\mathrm{WS}_{\mathrm{VFP}}(22.7), \mathrm{WS}_{\mathrm{F}}(10.2)$ and $\mathrm{WS}_{\mathrm{P}}$ (19.5).

Percentage increase in activity of enzyme catalase as depicted in Fig. 3 was highest in RSG963 under stress treatments $\mathrm{WS}_{\mathrm{VFP}}(25.3), \mathrm{WS}_{\mathrm{F}}$ (11.4) and $\mathrm{WS}_{\mathrm{P}}$ (21.3), among tolerant genotypes, while lesser percentage increase within sensitive genotypes was observed in GL22044 under stress treatments $\mathrm{WS}_{\mathrm{VFP}}(16.5), \mathrm{WS}_{\mathrm{F}}$ (7.60) and $\mathrm{WS}_{\mathrm{P}}$ (9.30). Glutathione reductase enzyme activity was less in control, and it enhanced under water stress treatments, magnitude of increase was greater as the level of water stress increased (Fig. 4). Among tolerant genotypes, highest increase was observed in RSG963 under water stress treatment $\mathrm{WS}_{\mathrm{VFP}}$ (41.2) and $\mathrm{WS}_{\mathrm{F}}$ (23.7). Among sensitive genotypes, least increase in enzyme activity was found in GL22044 under $\mathrm{WS}_{\mathrm{VFP}}$ (26.6) and $\mathrm{WS}_{\mathrm{P}}(22.8)$, whereas under $\mathrm{WS}_{\mathrm{F}}$, minimum increase in enzyme activity was observed in PBG1 (15.9) followed by GL22044 (16.9).

Water deficit leads to an imbalance between antioxidant defenses and reactive oxygen species resulting in oxidative stress. This study revealed enhancement in antioxidant enzyme activity showing their ameliorative effect under moisture stress. SOD activity is substrate inducible, and may be attributed to increased production of reactive oxygen species, leading to overexpression of genes encoding SOD, which if accompanied by enhanced $\mathrm{H}_{2} \mathrm{O}_{2}$ scavanging systems like catalase and peroxidase enzyme activities is considered as an important anti drought mechanism to cope with oxidative stress during water deficit conditions (Mckersie et al 1999). In accordance with our results, higher peroxidase, superoxide dismutase and catalase activity was reported in chickpea (Patel and Hemantaranjan 2012). Glutathione has antioxidant properties since thiol group in its cydtein moiety is a reducing agent and can be reversibly oxidized and reduced. Enhanced activity of Glutathione reductase has been reported by Sharada and Naik (2011) in Arachis hypogeal L..

Protein profiling: SDS-PAGE results revealed no significant effect of treatments, until severe stress under $\mathrm{WS}_{\mathrm{VFP}}$ was experienced by crop, on the protein of the SDS-PAGE. Electrophoretic analysis of total proteins in seeds from control (Plate 1) revealed that bands of more than $96 \mathrm{KDa}$ molecular weight, were more intense in GL28151 and PDG3 and less intense in GNG1861 and PBG1. In seeds derived from $\mathrm{WS}_{\mathrm{VFP}}$ (Plate 1), $96 \mathrm{KDa}$ molecular weight proteins were less intense in GNG1861 and completely missing in PBG1. Bands of $45 \mathrm{KDa}$ molecular weight showed heterogeneity, bands of higher intensity observed in tolerant (GL28151, RSG963 and PDG3) than sensitive (GL22044, GNG1861 and PBG1) genotypes.

SDS-PAGE results revealed no significant effect of treatments, until severe stress under $\mathrm{WS}_{\mathrm{VFP}}$ was experienced by crop, the overall pattern of seed storage proteins showed low degree of heterogeneity, moreover the changes which were observed were mainly due to the differences in the genome rather than the treatment indicating that seed protein composition is mainly controlled by genetic factors rather than environment. In accordance with our study, were the results observed by Mansourifar et al (2011), where severe drought stress had noticeable effect on protein banding patterns, however other water stress treatments showed no significant effect as observed in chickpea seeds.

\section{Conclusion}

Genotypic variations were prominent in response to moisture stress that underlines tolerance of RSG963 and sensitivity of GL22044 towards moisture stress. Remarkable variability observed under different stress treatments lay emphasis on podding as critical stage for irrigation after treatment sown with one presowing irrigation $\left(\mathrm{WS}_{\mathrm{VFP}}\right)$. This study may contribute towards identification of physiological and biochemical markers for drought resistance breeding programmes.

\section{ACKNOWLEDGEMENTS}

The authors wish to thank Department of Plant Breeding and Genetics, Punjab Agricultural University, Ludhiana, Punjab, India for providing facilities to carry out this research work.

\section{REFERENCES}

Ali, Q. and Ashraf, M. (2011). Induction of drought tolerance in maize (Zea mays L.) due to exogenous application of trehalose: growth, photosynthesis water relations and oxidative defence mechanism. Journal of Agronomy and Crop Sci., 1: 1-14.

Basu, P.S., Berger, J.D., Turner, N.C., Chaturvedi, S.K., Ali, M. and Siddique, K.H.M. (2007). Osmotic adjustment 
of chickpea (Cicer arietinum L.) is not associated with changes in carbohydrate composition or leaf gas exchange under drought. Ann. App. Biol, 150: 217-25.

Bates, L.S., Waldren, R. and Pand-Teare, I.D. (1973). Rapid determination of free proline for moisture stress studies. Plant Soil, 39: 205-07.

Bernheim, F., Bernheim ,M.L.C. and Wilbur, K.M. (1948), The reaction between thiobarbituric acid and the oxidation products of certain lipids. J. Biol. Chem., 174: 25464.

Bhatnagar-Mathur, P., Rao, S., Vadez, V., Devi, M.J., Lavanya, M., Vani, G. and Sharma, K.K. (2009). Genetic engineering of chickpea (Cicer arietinum L.) with the P5CSF 129A gene for osmoregulation with implications on drought tolerance. Mol. Breeding 23: 591-06.

Demidchik, V., Straltsova, D., Medvedev, S.S., Pozhvanov, G.A., Sokolik. and Yurin,V. (2014). Stress-induced electrolyte leakage: the role of $\mathrm{K} \pm$-permeable channels and involvement in programmed cell death and metabolic adjustment. J. Exp. Bot..65: 1259-70.

Dubois, M., Gilles, K.A., Hamilton, J.K., Roberts, P.A. and Smith, F. (1956). Calorimetric methods for the determination of sugars and related substances. Anal. Chem., 28: $350-56$.

Esterbauer, H. and Grill, D. (1978). Seasonal variation of glutathione and glutathione reductase in needles of Picea abies. Plant Physiol., 62:119-21.

FAOSTAT Food and Agriculture Organization of the United Nations (FAO) Statistical Databases from http:// www .fao.org (2014).

Fletcher, R.A. and Drexlure, D.M. (1980). Interactions of dichloromethyl and 2, 4-D in cultivated oats (Avena sativa) Weed Sci., 28: 363-66.

Hendry, G.A. (2005). Oxygen free radical process and seed longevity. Seed Sci. J., 3: 141-47.

Kar, M. and Mishra, D. (1976). Catalase, peroxidase and polyphenoloxidase activities during rice leaf senescence. Plant Physiol., 57: 315-19.

Lobato, A.K.S., Costa, R.C.L., Oliveira Neto, C.F., Santos Filho, B.G., Cruz, F.J.R., Freitas ,J.M.N., Cordeiro, F.C. (2008). Morphological changes in soybean under progressive water stress. Int. J. Bot., 4:231-35.

Laemmli, U.K. (1970). Cleavage of structural proteins assembly of the head of bacteriophage T4. Nature, 22: 680-85.

Mansourifar, C., Shaban, M., Ghobadi, M. and Ajirlu, A.R.
(2011). Effect of drought stress and $\mathrm{N}$ fertilizer on yield, yield components and grain storage proteins in chickpea (Cicer arietinum L.) cultivars. Afr. J. Pl. Sci., 5: 634-42.

Masoumi, H., Darvish, F., Daneshian, J., Normohammadi, G. and Habibi, D. (2011). Effects of water deficit stress on seed yield and antioxidant content in soybean (Glycine $\max$ L.) cultivars. Afr. J. Agric. Res., 6: 1209-18.

McKersie, B.D., Bowley, S.R., and Jones, K.S. (1999). Winter survival of transgenic alfalfa overexpressing superoxide dismutase. Plant Physiol., 119: 839-47.

Moinuddin and Khanna-Chopra, R. (2004). Osmotic adjustment in chickpea in relation to seed yield and yield parameters. Crop Sci., 44: 449-55.

Nishikimi, M., Rae, N.A. and Yagi, K. (1972). The occurrence of superoxide anion in the action of reduced phenazine methosulphate and molecular oxygen. Biochem. Biophys. Res. Commun., 46: 849-53.

Patel, P.K. and Hemantaranjan, A. (2012). Salicylic acid induced alteration in dry matter partitioning, antioxidant defence system and yield in chickpea (Cicer arietinum L.) under drought stress. Asian J. Crop Sci., 4: 86-02.

Patel, P.K., Hemantaranjan, A., Sarma, B.K. and Singh, R. (2011). Growth and antioxidant system under drought stress in Chickpea (Cicer arietinum L.) under drought stress. Asian J. Crop Sci., 4: 86-02.

Pratap, V., and Sharma, Y.K. (2010). Impact of osmotic stress on seed germination and seedling growth in black gram (Phaseolus mungo). J. Environ. Biol., 31: 721-26.

Raheleh,R., Ramazanali, K.N., Ali, G., Abdolreza, B., Farzaneh, N. and Masoud, R. (2012). Use of biochemical indices and antioxidant enzymes as a screening technique for drought tolerance in Chickpea genotypes (Cicer arietinum L.). Afr. J. Agric. Res., 7: 5372-80.

Sharada , P. and Naik, G.R. (2011). Physiological and biochemical responses of groundnut genotypes to drought stress. World J. Sci.Tech., 1: 60-66.

Sumithra, K. and Reddy, A.R. (2004). Changes in proline metabolism of cowpea seedlings under water deficit. $J$ Plant Biol., 31: 201-04.

Sunkar, R. (2010). Plant stress tolerance. Methods Mol. Biol., 639.

Weatherly, P.E. (1950). Studies of the water relations of the cotton plant. I. The field measurements of water deficits in leaves. New Phytol., 49: 81-87. 